\title{
Correlation of electrocardiographic parameters (heart rate variability and heart rate) with Obel grading of pain of horses with laminitis
}

\author{
Claudia Halmer ${ }^{1 *}$, Katrin Franken ${ }^{1,2^{*}}$ and Theresia Licka ${ }^{1,3}$ \\ * The two authors have contributed equally to this study. \\ 1 Department 4, Veterinary University Vienna \\ ${ }^{2}$ Centre for Neuroregeneration, University of Edinburgh, Schottland, UK \\ ${ }^{3}$ Royal (Dick) School of Veterinary Studies, University of Edinburgh, Schottland, UK
}

\begin{abstract}
Summary: Heart rate variability (HRV) has frequently been used to evaluate pain and/or stress in nonverbal species. In the present study it was used to gain more information about the pain state of laminitis than is offered by the heart rate (HR) alone, which is commonly used to this end. This is based on the theory that a lower HRV corresponds to a higher degree of pain. In 12 horses clinically affected by laminitis HR (in beats per minute, BPM) and HRV were collected over several hours using a telemetric heart rate monitoring system (Polar), and subsequently compared to HR and HRV of healthy control horses (5). For further data processing HRV batches of 100 and 500 consecutive heart beats were selected, and of the HRV the root mean square of the successive RR differences (RMSSD) was calculated. Mean HR was significantly higher in the laminitic group at the first measurement after clinic admission (50 \pm 10 BPM), than in the control group $(40 \pm 2$ BPM; $p=0.04)$. The RMSSD of the 100 beat batches (RMSSD100) was significantly lower in the laminitic group at the first measurement after clinic admission (140 120$)$ than in the control group (162 $\pm 9, p=0.04)$. There was no significant difference between the control group and the laminitic group at the second measurement after clinic admission for either HR or RMSSD100, while RMSSD500 was not different between the groups at any of the time points. At the first evaluation after admission to the clinic there was a highly significant positive correlation between Obel grade and heart rate $(0.625, p=0.007)$, as well as a highly significant negative correlation between Obel grade and RMSSD $100(-0.653, p=0.005)$. The present study suggests that HRV is of only limited additional benefit for the evaluation of even considerably severe laminitic pain in the horse compared to HR. Therefore the additional effort to obtain HRV may not be justified, as HR is obtained during the routine clinical examinations anyway.
\end{abstract}

Keywords: laminitis / heart rate / heart rate variability / RMSSD / pain / horse

Citation: Halmer C., Franken K., Licka T. (2014) Correlation of electrocardiographic parameters (heart rate variability and heart rate) with Obel grading of pain of horses with laminitis. Pferdeheilkunde 30, 140-147

Correspondence: Prof. Theresia Licka, Department 4, Veterinary University Vienna, Veterinärplatz 1, A-1210 Vienna, Austria. Email: theresia.licka@vetmeduni.ac.at

\section{Introduction}

Pain is defined as an aversive, sensory and emotional experience, through which an animal may identify tissue damage or the risk of tissue damage; in the presence of pain, physiology and behavior are changed to avoid or reduce tissue damage, and to decrease the likelihood of further pain and to allow healing (Molony 1997). Pain can be useful and protective and it is commonly inflammatory or traumatic, with most inflammatory pain decreasing adequately with non-steroidal anti-inflammatory drugs (Driessen et al 2007).

On the other hand, pathological pain does not have biological advantages leading to the individual's suffering and stress (Woolf et al. 1999). One form of this pathological pain is neuropathic pain often associated with laminitis; it is caused by damage to the sensory nerves and changes in the neurons, with hyperalgesia, allodynia and spontaneous pain being its main characteristics. This can develop into chronic pain, in which analgesic drugs are less effective (Jones et al. 2007). In humans it was shown, that patients with neuropathic pain suffer continuous pain or bouts of pain, in many instances without exposure to any stimulation (Woolf et al. 1999).

As the disease process of laminitis causes many changes, the pain present in a laminitic horse consists of many facets such as inflammatory pain, pain due to tissue damage and also neuropathic pain caused by nerve damage and an abnormal function of the nervous system (Driessen et al 2007, Collins et al. 2010). Animals that have developed laminitis are often suffering severely, and have to be euthanized, and therefore assessing the degree of pain present is important for ethical, therapeutic and prognostic considerations (Driessen et al. 2007, Collins et al. 2010, Bussières et al. 2008).

Effective pain assessment should ideally involve many pain parameters such as intensity, frequency of bouts of pain, duration, and quality; it should also be species and breed specific (Ashley et al. 2005). Pain assessment depends on sensitive and reproducible examination techniques, such as the examination using hoof testers on the laminitic foot (Vinuela-Fernandez et al. 2007, Vinuela-Fernandez et al. 2011 ).

When assessing pain in laminitic horses, the grading system according to Obel is commonly used (Budras et al. 2006). Additionally, there are also grading scales, which combine behavioural parameters with physiological parameters. These are useful to determine the degree of pain with some accuracy; however they are not specific for the source and the type of pain. 
In laminitis research experimental disease induction has been commonly used to elucidate the pathomechanisms of this disease. These experimental studies offer essential information to increase the understanding of laminitis, even if they are only partly true to the naturally occurring disease. In many of these studies the development of clinical laminitis was also monitored using heart rate $(H R)$, with significant heart rate increases determined in laminitic horses after administration of oligofructose which decreased later with adequate cryotherapy (van Eps et al. 2006, 2009). Similarly, heart rate increased in ponies where laminitis was induced by allowing them onto rich pasture (Hinckely et al. 1996). This supports the fact that laminitic pain leads to an increase in HR (Orsini et al. 2003) and also, the degree of pain is reflected in the HR (Brown et al. 2002).

In order to gain more information from the HR, evaluation of HRV was introduced, with the hypothesis, that lower HRV is equivalent to a higher degree of pain (Rietmann et al. 2004) or possibly a stimulation of the sympathetic nervous system (Stewart et al. 2008). The variability of consecutive heart beats allows the assessment of the autonomous nervous system with both sympathetic and parasympathetic influences on the heart (Task Force of The European Society of Cardiology and The North American Society of Pacing and Electrophysiology 1996).

Today many HRV studies in several species are available; however there is a lack of consistent standards for data analysis. This may have hampered the wide spread uptake of HRV as a useful addition for pain evaluation. In a study with mice experiencing postoperative pain the interval between two heart beats was assessed as interbeat intervals (IBI) and the standard deviation of these intervals was used for calculation of HRV. This study showed significant changes in HRV associated with pain (Arras et al. 2007). A study on calves after dehorning procedures with and without local anesthetic and non-steroidals respectively used the root mean square of successive RR differences (RMSSD) for pain assessment, as well as the high frequency of the data set (HF) for characterization of parasympathetic activity and low frequency (LF) for characterization of sympathetic activity, with the ratio HF/LF indicating the balance between these activities. The RMSSD of 512 consecutive IBls was calculated. Significant differences between groups were shown for HR and only partly for HRV (Stewart et al. 2008, Stewart et al. 2009). In another study of the same group on HR and HRV of calves after castration with and without local anesthetic significant differences between groups were also found (Stewart et al. 2010).

In a study on naturally occurring equine laminitis, Rietmann et al. (2004) investigated HR and HRV (assessed as RMSSD, HF, LF and HF/LF ratio) collected over ten minutes. This study showed significant differences in HR only, with none of the HRV parameters showing significant differences. Different from the usefulness of HR to assess pain (Stewart et al. 2010), HRV has not yet been established as a meaningful measure of pain in horses with laminitis, at least if it has been collected over ten minutes.

The aim of the present study was therefore to investigate the usefulness of assessing HRV as RMSSD to quantify pain in laminitic horses, in order to assess the possibilities of introducing this relatively easy and non-invasive measure for the use in clinics as well as in ambulatory practice.

\section{Materials and Methods}

\section{Horses}

For this study, 12 horses ( 7 mares and 5 geldings, 6-28 years) suffering from clinically obvious laminitis of varying degrees were investigated (Table 1). Each of these horses showed a minimum Obel grade of 1 and a maximum Obel grade of 3.5. At Obel grade 1 horses were weightshifting at stance, and they were noticeably short strided at trot; at Obel grade 2 horses were short strided and stabbing at the walk, at Obel grade 3 horses moved reluctantly and resisted attempts to lift feet, and at Obel grade 4 horses showed marked reluctance or absolute refusal to move. Additionally, radiographic signs of pedal bone rotation and/or sinking of the pedal bone within the hoof capsule bilaterally on the fore and/or hind limbs were present in all horses (Table 2). All horses with laminitis were patients at the Equine Clinic at the

Table 1 Horses included in this study that were suffering from laminitis. Breed, sex, age and the highest Obel grade obtained during the time the horses were at the clinic are listed.

\begin{tabular}{clccc}
\hline Horse & Breed & Sex & Age (years) & Obel grade \\
\hline 1 & Dutch Warmblood & Mare & 14 & 11 \\
2 & Tinker & Gelding & 17 & 2 \\
3 & Haflinger & Mare & 18 & 1,5 \\
4 & Standardbred Trotter & Mare & 17 & 2 \\
5 & Warmblood & Gelding & 17 & 3 \\
6 & German Warmblood & Mare & 28 & 3 \\
7 & Hunter & Gelding & 6 & 3,5 \\
8 & Coldblood (Noriker) & Stallion & 21 & 2 \\
9 & Arabian Horse & Mare & 17 & 1 \\
10 & Arabian Horse & Mare & 11 & 3 \\
11 & Icelandic Horse & Mare & 16 & 3 \\
12 & Hanoveranian & Gelding & \\
\hline
\end{tabular}


Veterinary University Vienna, and they were treated routinely, without any influence of the present study, by the veterinary surgeons responsible. Treatments included non-steroidal drugs, acepromazine, as well as trimming of the hooves, removal of shoes, ice and others. Patients were fed with wet hay, and during the measurements with the electrocardiography belt they were free to move or to lie down in their stables. Of these 12 horses, three were euthanased and nine were discharged again depending on the joint decision of the veterinary surgeons responsible and the owners.

As control group, 5 horses free from laminitis (Obel grade 0), as well as free from lameness at walk were chosen. Also, detailed clinical examination did not reveal any pain from other processes. Two of these control horses (both geldings, 8 and 20 years old) were patients at the Equine Clinic at the Veterinary University Vienna, one was admitted for arthroscopy of osteochondral chips in the talocrucal joint, and one for removal of new bone formation on a splint bone. The remaining three horses were ponies owned by the Easter Bush Veterinary Centre der Royal (Dick) School of Veterinary Studies, University of Edinburgh.

\section{Data collection}

Data of the horses at the Equine Clinic of the Veterinary University Vienna was collected throughout the evening and night hours, in order to reduce disturbances such as noise or other horses walking past. Prior to each measurement, HR and respiratory rate were noted. If horses were recumbent at the planned time of starting the data collection, they were not asked to rise, but data collection was postponed until they rose by themselves. At stance, the heart rate monitor unit (s 810 i, Polar Electro Oy, Helsinki, Finland) was placed over the cranial aspect of the thorax; two electrodes were placed on the left side of the thorax and kept in place with a sticky elastic bandage (width $8 \mathrm{~cm}$, Elastoplast now Optiplast, BSN medical $\mathrm{GmbH}$, Hamburg, Germany) and in order to increase conductivity gel was applied on the coat at the sites of the electrodes. The main collection unit, which is similar to a heart rate monitor wrist watch, was placed underneath an elastic surcingle caudal to the bandage that secured the elec- trodes. Then, HRV was collected continuously over several hours, with horses free to move within their stables, to eat or drink and to lie down. During the routine clinical observation rounds throughout the night, additional observations such as "horse in sternal recumbency" were noted by the clinic team, but the stables were not entered. In the patients, this data collection was done for the first time within the first 5 days after admission at the clinic, and on up to three consecutive nights, followed by once weekly measurements; resulting in data collection on a minimum of 2 and a maximum of 7 nights for all patients. Control horses were measured similarly, but only at a single time point.

\section{Data processing and further analysis}

In the morning, the data collected throughout the night in the heart rate monitor was transmitted via infrared to a laptop with the suitable software (Polar Electro Oy, Helsinki, Finland), from which data was exported to a commercial spreadsheet software (Microsoft Excel). In order to remove artefacts commonly encountered with slight electrode movement, data was filtered, and only RR intervals that were between $600 \mathrm{~ms}$ (equivalent to a heart rate of $100 / \mathrm{min}$ ) and $3000 \mathrm{~ms}$ (equivalent to a heart rate of $20 / \mathrm{min}$ ) were further processed. Additionally, RR intervals that were more than twice the standard deviation removed from the mean RR interval were considered as outliers, and removed. As a consequence of this values were missing from the processed data, and as HRV is really dependent on consecutive data sets, only batches of 100 or 500 consecutive RR intervals were further analysed by calculating the root mean square of successive RR differences (RMSSD) of these batches as RMSSD100 and RMSSD500, respectively. In the present study RMSSD was used as HRV parameter, as it is most commonly used to date.

\section{Statistical analysis}

Data was tested for parametric distribution using the Kolmogorov Smirnov Test, and parametric data was then presented as mean and standard deviation. For comparisons of the HR, the RMSSD100 and the RMSSD500 collected at the time

\begin{tabular}{|c|c|}
\hline Horse & Radiological Findings \\
\hline 1 & FL bilateral $8^{\circ}$ Rot, pedal bone at the point of solar penetration \\
\hline 2 & $\mathrm{FL} \mid 1^{\circ}$ Rot, $\mathrm{HE} \mid 14^{\circ}$ Rot, $\mathrm{r} 13^{\circ}$ Rot \\
\hline 3 & $\mathrm{FL} \mid 6^{\circ}$ Rot, $\mathrm{r} 7^{\circ}$ Rot \\
\hline 4 & $\mathrm{FL} \mathrm{I} 15^{\circ}$ Rot and sinking of pedal bone, $\mathrm{r} 10^{\circ}$ Rot; $\mathrm{HL} \mid 1^{\circ}$ Rot, $\mathrm{r} 3^{\circ}$ Rot, bilateral marked sinking of pedal bones \\
\hline 5 & $\mathrm{FLI} 8^{\circ}$ Rot, $\mathrm{r} 17^{\circ}$ Rot \\
\hline 6 & $\mathrm{FL} \mid 6^{\circ}$ Rot, $\mathrm{r} 16^{\circ}$ Rot, $\mathrm{HL} \mid 12^{\circ}$ Rot, $\mathrm{r} 6^{\circ}$ Rot \\
\hline 7 & $\mathrm{FL} \mid 4-5^{\circ}$ Rot, $\mathrm{r} 4-6^{\circ}$ Rot \\
\hline 8 & FL bilateral $2^{\circ}$ Rot, $\mathrm{HL} \mid 2^{\circ}$ Rot, $r 1^{\circ}$ Rot \\
\hline 9 & $\mathrm{FL} \mid 14^{\circ}$ Rot, $\mathrm{r} 10^{\circ}$ Rot \\
\hline 10 & FL bilateral $6-7^{\circ}$ Rot \\
\hline 11 & $\mathrm{FL} I 1^{\circ}$ Rot, $\mathrm{r} 2^{\circ}$ Rot, $\mathrm{r} 3^{\circ}$ Rot \\
\hline 12 & $\mathrm{FL} 11^{\circ}$ Rot, $\mathrm{r} 3^{\circ}$ Rot, bilateral sinking of pedal bones \\
\hline
\end{tabular}


points 1 to 5 of the laminitic group, with the data of the control group the independent two sided T test was used. There were not enough data points collected at the time points 6 and 7 , and these were therefore excluded from the statistical comparisons. In order to assess correlations between the parameters obtained, Pearson's correlation coefficients were calculated between HR and RMSSD100, HR and RMSSD500, HR and Obel grades, RMSSD100 and RMSSD500, HR and Obel grades, RMSSD 100 and Obel grades and RMSSD500 and Obel grades.

Table 3 Heart rate (HR) in beats per minute (BPM) of all horses. HR was obtained on several measurements (HR 1 - HR7) over a number of days, not necessarily on consecutive days. Measurements of HRV (RMSSD100, RMSSD500) and of HR were obtained simultaneously. Horses suffering from laminitis numbers 1-12, control horses C1-C5.

\begin{tabular}{|c|c|c|c|c|c|c|c|}
\hline Horses with laminitis & HR 1 & HR 2 & HR 3 & HR 4 & HR 5 & HR 6 & HR 7 \\
\hline 1 & 45,84 & 49 & 40 & 46,26 & 39,45 & & \\
\hline 2 & 40,72 & 40,03 & 39,3 & 37,54 & 39,75 & 44,8 & 39,3 \\
\hline 3 & 57,34 & 41,89 & 39,4 & 48,3 & 46,87 & 46,6 & \\
\hline 4 & 40,14 & 36,26 & 41,5 & 39,03 & 52,41 & 38,8 & \\
\hline 5 & 45,81 & 48,75 & 64,3 & 63,55 & 39,86 & & \\
\hline 6 & 71,56 & 64,82 & 43,4 & 36,26 & 39,62 & & \\
\hline 7 & 51,09 & 40,23 & 37,5 & 42,11 & & & \\
\hline 8 & 57,75 & 49,03 & 51,2 & 48,48 & 40,16 & & \\
\hline 9 & 42,73 & 43,66 & 49,6 & 51,86 & & & \\
\hline 10 & 41,02 & 39,21 & & & & & \\
\hline 11 & 57,96 & 86,66 & & & & & \\
\hline 12 & 44,44 & 51,41 & 34,4 & 33,11 & & & \\
\hline Control horses & $\mathrm{HR}$ & & & & & & \\
\hline $\mathrm{Cl}$ & 41,74 & & & & & & \\
\hline $\mathrm{C} 2$ & 38,68 & & & & & & \\
\hline C3 & 36,78 & & & & & & \\
\hline C4 & 40,94 & & & & & & \\
\hline C5 & 41,56 & & & & & & \\
\hline
\end{tabular}

Table 4 RMSSD obtained over 100 consecutive heart beats (RMSSD100) of all horses. RMSSD100 was obtained on several measurements (RMSSD100 1 - RMSSD100 7) over a number of days, not necessarily on subsequent days. Measurements of HRV (RMSSD100, RMSSD500) and of HR were obtained simultaneously. Horses suffering from laminitis numbers 1-12, control horses C1-C5.

\begin{tabular}{|c|c|c|c|c|c|c|c|}
\hline $\begin{array}{l}\text { Horses with } \\
\text { laminitis }\end{array}$ & $\begin{array}{c}\text { RMMSD100 } \\
1\end{array}$ & $\begin{array}{c}\text { RMSSD } 100 \\
2\end{array}$ & RMSSD100 3 & $\begin{array}{c}\text { RMSSD } 100 \\
4\end{array}$ & $\begin{array}{c}\text { RMSSD } 100 \\
5\end{array}$ & $\begin{array}{c}\text { RMSSD } 100 \\
6\end{array}$ & $\begin{array}{c}\text { RMSSD } 100 \\
7\end{array}$ \\
\hline 1 & 136,82 & 142,6 & 152,4 & 144,82 & 163,02 & & \\
\hline 2 & 156,81 & 160,57 & 156,96 & 168 & 167,8 & 157,19 & 174,29 \\
\hline 3 & 130,46 & 184,14 & 207,89 & 150,19 & 147,59 & 143,8 & \\
\hline 4 & 145,81 & 145,81 & 171,27 & 188,5 & 152,18 & 177,5 & \\
\hline 5 & 153,59 & 147,97 & 100,8 & 106,05 & 171,11 & & \\
\hline 6 & 97,78 & 109,24 & 161,67 & 194,01 & 167,35 & & \\
\hline 7 & 147,3 & 179,58 & 170,53 & 155,65 & & & \\
\hline 8 & 114,98 & 131,78 & 137,52 & 146,85 & 172,82 & & \\
\hline 9 & 163,78 & 153,63 & 133,26 & 136,65 & & & \\
\hline 10 & 159,76 & 161,78 & & & & & \\
\hline 11 & 122,97 & 80,13 & & & & & \\
\hline 12 & 145,61 & 149,31 & 189,39 & 208,07 & & & \\
\hline Control horses & RMSSD 100 & & & & & & \\
\hline $\mathrm{Cl}$ & 157,57 & & & & & & \\
\hline $\mathrm{C} 2$ & 164,28 & & & & & & \\
\hline $\mathrm{C} 3$ & 176,22 & & & & & & \\
\hline $\mathrm{C} 4$ & 157,45 & & & & & & \\
\hline C5 & 155,11 & & & & & & \\
\hline
\end{tabular}




\section{Results}

The details of the horses of the laminitis group and of their laminitis symptoms are given in Table 6. The first data collection was carried out on the day of admission at the clinic in 2 horses, the day after clinic admission in 5 horses, 2 days after clinic admission in 4 horses, and in one horse 5 days after clinic admission. In 8 horses the second data collection was on the day after the first data collection, in 3 horses 2 days after the first data collection, and in one horse 2 weeks after the first data collection. The third data collection was carried out the day after the second data collection in 7 horses, 2 days after the second data collection in 2 horses, in 1 horse 3 days and in 1 horse 11 days after the second data collection. In 2 horses no third measurement was carried out.
Heart rate was significantly higher in the laminitis group on the first day of data collection (50 \pm 10 BPM) than in the control group $(40 \pm 2$ BPM, $p=0,04)$ (Table 3). At this time point there was also a significant difference between RMSSD100 of

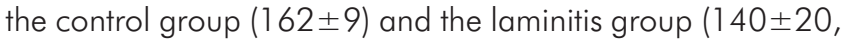
$p=0,04)$ (Table 4). At the first data collection there was no significant difference between RMSSD500 of either groups (Table 5), and from the second data collection onwards, there were no significant differences between the groups for any of the parameters assessed.

There were significant correlations between $H R$ and RMSSD100 (-0,937, $p=0,000)$, between $H R$ and RMSSD500 $(-0,531 p=0,03)$, between RMSSD100 and RMSSD500 $(0,506, p=0,04)$. There was a significant corre-

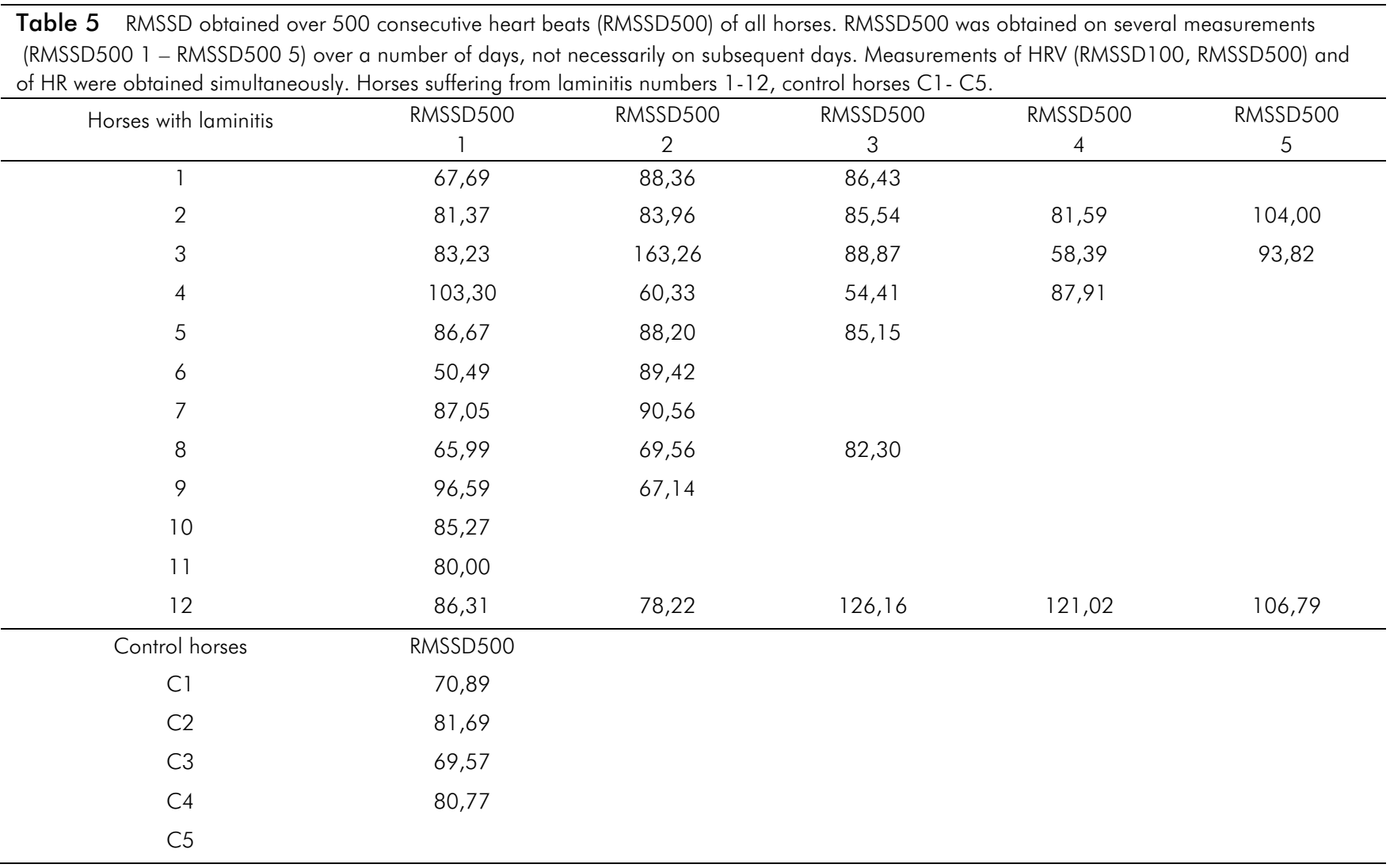

Table 6 Obel grades of all the horses suffering from laminitis and included in this study. The Obel grade on the day of admission, the highest Obel grade during the time at the clinic, and the Obel grade on the day of discharge from the clinic or euthanasia (euth) is listed.

\begin{tabular}{|c|c|c|c|}
\hline Horses with laminitis & OBEL grade on admission & OBEL highest grade & OBEL at discharge or euthanasia \\
\hline 1 & 2,5 & 3 & 3 (euth) \\
\hline 2 & 2 & 2 & 1 \\
\hline 3 & 1,5 & 1,5 & 1 \\
\hline 4 & 1 & 1 & 1 \\
\hline 5 & 2 & 2 & 1 \\
\hline 6 & 2 & 3 & 2 \\
\hline 7 & 3 & 3 & 1,5 \\
\hline 8 & 3,5 & 3,5 & 3,5 (euth) \\
\hline 9 & 1,5 & 2 & 1 \\
\hline 10 & 1 & 1 & 1 \\
\hline 11 & 3 & 3 & 2,5 \\
\hline 12 & 2 & 3 & 3 (euth) \\
\hline
\end{tabular}


lation between Obel grades and $\mathrm{HR}$ at the first data collection point $(0,625, p=0,007)$ and between Obel grades and RMSSD100 at the first data collection point $(-0,653$, $p=0,005)$, while there was no significant correlation between Obel grades and RMSSD500.

\section{Discussion}

The study of Rietmann et al. (2004), where horses were measured over periods of 10 minutes in a standardized setting tied to the wall with their head collars, found correlations of both $\mathrm{HF}$ and LF with the Obel grades and with the reaction to hoof testers; HF also correlated with weightshifting. Because of the results of this study, we chose a longer period of data collection for the present study, but without influencing the normal behaviour of the horses within their stable, in order to make the data collection more feasible in a standard clinical setting. The long data collection period of up to 10 hours therefore included most horses walking in their stable, many of them also lying down. The basically similar result of both studies shows that the longer data collection period is not superior to the shorter data collection time, and most likely this is due to the reduced standardization of the measurement set-up.

In a study of Erber et al. (2012), where HR and HRV of foals undergoing either hot-iron branding or implantation of a microchip were compared, a similar increase of HR was found in both groups, but HRV remained unchanged throughout the procedure in both groups. The authors explain that the painful impulse may be too short to have an effect on $H R V$, whereas HR is more sensitive to such short term influences. In the present study dealing with horses that were clinically affected by laminitis usually over several days prior to admission at the clinic, one of the HRV parameters investigated, that is RMSSD100 was positively correlated with Obel grades. The difference in the results may well be explained by the chronicity of the laminitic pain, compared to the short duration of the pain during the identification procedures. There may thus be a limited use of HRV parameters for the evaluation of pain in horses affected by chronic severe pain.

Stewart et al (2010) describe in their study, that HR and HRV are complementing each other and that addition of methods such as infrared thermography of the lower eye lid and the lacrimal duct further improve evaluation of pain after castra- tion or dehorning procedures. In the present study, HR was more closely correlated with Obel grades than the HRV parameters. This should not be interpreted as superiority of evaluating $H R$ as a single measure compared to the combination of several measures. In the present study however, HR alone has again been shown to be an important pain parameter, and as it is commonly obtained several times during the day in the clinical routine, it is also a very practical pain parameter.

Not surprisingly, and similar to the present study, Stubsjoen et al. (2009) found a low RMSSD associated with a high HR in the sheep used for the experiment, and they were happy to recommend HRV as a useful method to evaluate moderate pain. In another study by the same research group, Stubsjoen et al. (2010) carried out further fractal analysis of the sheep $\mathrm{HR}$, and they could not document differences in the coefficient alpha of HRV. The findings of both these studies may be slightly limited due to the small number of animals investigated.

In the present study an adequate number of horses suffering from laminitis were used, and that these animals were showing the naturally occurring disease may have been an advantage as well as a disadvantage. While many studies have experimentally induced short term laminitis in horses that were reasonably young and healthy at the start, horses with the naturally occurring disease may have had some predisposing factors over longer periods of pain, or even very mild bouts of laminitis that went unnoticed. Especially as the aim of the present study was to find pain evaluation parameters that are suitable for the clinical routine, using animals that were presented for naturally occurring disease makes the findings more pertinent. On the other hand, a higher degree of standardisation of the study population may have created more significant differences. The data collection on the five control horses was also used to identify the correlation between HR, RMSSD100 and RMSSD500 in healthy horses. Due to the small number of control horses, HRV values published in other studies were used for additional comparisons (Table 7).

Arras et al. (2007) explain in their study, that HR and HRV could potentially be useful for evaluation of post-surgical pain, if measurements are carried out in a standardized setting and in a quiet environment. Even though we agree about this, it is not feasible in horses with varying degrees of lamini-

Table 7 Comparative RMSSD and or RR values (in millisecon not obtained in this study this is indicated by not applicable (NA). ds, ms) of healthy horses of other studies investigating HRV. If values were

\begin{tabular}{|c|c|c|c|c|}
\hline Authors & RMSSD & Sequences analysed & RR Intervals & Sequences analysed \\
\hline \multirow{3}{*}{ Gehrke et al 2011} & $123+/-69 \mathrm{~ms}$ & 5 min sequences selected & NA & \multirow{3}{*}{ NA } \\
\hline & $115+/-68$ ms day & from 24 hour & NA & \\
\hline & $152+/-86 \mathrm{~ms}$ night & measurements & NA & \\
\hline Schmidt et al 2010a & NA & 30 min sequences & $1551+/-23 \mathrm{~ms}$ & 30 min sequences \\
\hline Schmidt et al $2010 b$ & $74+/-12 \mathrm{~ms}$ & 30 min sequences & $1635+/-71 \mathrm{~ms}$ & 30 min sequences \\
\hline \multirow{3}{*}{ Schmidt et al $2010 c$} & NA & NA & $1605+/-107 \mathrm{~ms}$ & 30 min sequences \\
\hline & $74+/-5 \mathrm{~ms}$ & \multirow{2}{*}{30 min sequences } & $1742+/-64 \mathrm{~ms}$ & \\
\hline & $89+/-7 \mathrm{~ms}$ & & $1675+/-55 \mathrm{~ms}$ & $30 \mathrm{~min}$ sequences \\
\hline \multirow{2}{*}{ Minero et al 2006} & $83.98 \mathrm{~ms}$ (therapy horses) & \multirow{2}{*}{5 min sequences } & 1419 ms (therapy horses) & \multirow[t]{2}{*}{5 min sequences } \\
\hline & $62.78 \mathrm{~ms}$ (showjumpers) & & 1596 ms (showjumpers) & \\
\hline
\end{tabular}


tis that may need to lie down. The difficulties of standardizing data collection are well described in the study of Rietmann et al. (2004), even though in their study only 10 minutes of standardized data collection was necessary. These authors also consider it possible, that examining horses of the same age and breed, pain quantification based on HRV analysis may be feasible. Such studies are still lacking in horses, while in other species experiments with similar pain stimuli were carried out on several animals of the same breed and age (calves Stewart et al. 2008, 2009, 2010, sheep Stubsiøen et al 2009).

For the future, Rietmann et al. (2004) suggest studies involving larger and more homogenous study populations, as the duration of the presence of pain and the breed may influence HRV. In a clinical study, based on patients suffering from naturally occuring disease this is hardly feasible. Even in standardized studies on experimentally induced laminitis a variety of Obel grades resulted, despite the use of horses of the same breed and the same laminitis induction methods (Galey et al. 1991, van Eps et al. 2006) or ponies of different breeds and the same laminitis induction method (Hinckley et al 1996).

Using HRV is advantageous for the assessent of acute pain responses according to Stewart et al (2008); the horses used in the present study were suffering from severe but not really acute pain, with all of them showing a minimum of 12-24 hours of laminitic pain prior to admission at the clinic. In most horses, laminitis was clinically obvious for several days prior to admission at the clinic. Prior to admission at the clinic eight horses had already been treated with non-steroidal antiinflammatory drugs, two had previously been treated with non-steroidal anti-inflammatory drugs but were without treatment on the day of clinic admission, and two were without treatment prior to admission. Based on this variety, the time delay between admission at the clinic and the first data collection is acceptable. For a higher scientific quality of the stu$d y$, horses should have been measured on the day of the first clinical signs and symptoms of laminitis; this would certainly have increased the value of the study.

Stewart et al (2009) found changes only in RMSSD and they are considering whether their use of 512 RR intervals may be the cause for this, as in other studies 5 minute sequences were analysed, and depending on the heart rate of the sheep used, this may be less than 512 beats.

The method of data collection for HRV is obviously a major influence on the usefulness of the results for pain evaluation. In HRV of horses there is a large interindividual variation, this is depending on the genotype, behavior, body condition and feeding (van Borell et al 2007). This is a larger variability than in humans, and up to now no standardized protocols for data collection and analysis have been established, so that interpretation of HRV data of animals should always be done exerting considerable caution (Munsters et al 2012).

Van Borell et al. (2007) are stipulating that for the method of HRV analysis age, sex and time of day of the data collection should be standardized and documented. Also, as there is a large interindividual variation, HRV comparisons within the same animal before and after treatments or interventions are more reliable than the comparison of groups. In the present study, we therefore obtained several sets of data of the same animal throughout the course of its laminitis disease. Also, we could analyse at least once for each horse sequences obtained over 5 minutes or 500 heart beats (which in all our horses is longer than 5 minutes). As discussed above, the standardization of breed, sex age and grade of laminitis was not possible in the clinical setting.

Many artefacts were present in the recordings, and therefore it was not possible to analyse RMSSD500 for each data collection point, while RMSSD 100 sequences were always available for analysis at each data collection point. Using such small batches of heart beats for HRV analysis may be questionable as such, as clearly a measure of variability depends largely on the number of values analyzed. However, in the present study, RMSSD100 was showing significant differences, and it was also highly significantly (negatively) correlated to the Obel grades of the laminitic horses. In the present study this was never the case for RMSSD500.

Munsters et al (2012) state that further research is necessary in order to evaluate in detail the method, its reliability and its relevance for HRV analysis in horses, a statement that we fully agree with. Even in human medicine, where the method comes from, and where it is more widely used, this is still an issue. Demands for uniform methods and standardized data treatment as well as similar data collection are often repeated (Sandercock et al. 2005, Pinna et al. 2007).

The present study shows that in cases of naturally occurring laminitis the use of HRV as obtained in this study is not superior to the use of HR to evaluate the pain state of the horse. Therefore the additional effort to obtain HRV cannot be recommended if such a large variety of horses with such a variety of pain states should be assessed.

\section{References}

Arras M., Rettich A., Cinelli P., Kasermann H. P., Burki K. (2007) Assessment of post-laparotomy pain in laboratory mice by telemetric recording of heart rate and heart rate variability. BMC Vet. Res. 3, 16

Ashley F. H., Waterman-Pearson A. E., Whay H.R (2005) Behavioural assessement of pain in horses and donkeys: application to clinical practice and future studies. Equine vet. J. 37, 565-575

Brown C. M. (2002) Laminitis. In Brown C. M. and Bertone J.: The 5-Minute Veterinary Consult, Equine., Verlag Lippincott Williams \& Wilkins, Baltimore

Budras K.-D., Huskamp B., Schneider J. (2006) Hufkrankheiten, Hufrehe. In: Dietz O. and Huskamp B., Handbuch Pferdepraxis Verlag: Enke, 3rd edition 972-978

Bussiéres G., Jacques C., Lainay O., Beauchamp G., Leblond A., Cadoré J.-L., Desmaizières L.-M., Cuvelliez S. G., Troncy E. (2008) Res. Vet. Sci. 85, 294-306

Collins S. N., Pollit C., Wylie C. E., Matiasek K. (2010) Laminitic Pain: Parallels with Pain States in Humans and Other Species. Vet. Clin. Equine 26, 643-671

Driessen B., Bauquier S. H., Zarucco L. (2010) Neuropathic Pain Management in Chronic Laminitis. Vet. Clin. Equine 26, 315-337

Erber R., Wulf M., Becker-Birck M., Kaps S., Aurich J. E., Möstl E., Aurich C. (2012) Physiological and behavioural responses of young horses to hot iron branding and microchip implantation. Vet. J. 191, 171-175

Galey F. D., Whiteley H. E., Goetz T. E., Kuenstler A. R., Davis C. A., Beasley V. R. (1991) Black Walnut (Jugulans nigra) Toxicosis: A Model for Equine Laminitis. J. Comp. Path. 104, 313-326 
Gehrke E. K., Baldwin A., Schiltz P. M. (2011) Heart Rate Variability in Horses Engaged in Equine-Assisted Activities. Equine Vet. Sci. $31,78-84$

Hinckley K. A., Fearn S., Howard B. R., Henderson W. (1996) Nitric oxide donors as treatment for grass induced acute laminitis in ponies. Equine vet. J. 28, 17-28

Jones E., Vinúela-Fernandez I., Eager R. A., Delaney A., Anderson H., Patel A., Robertson D. C., Allchorne A., Sirinathsinghii E. C., Milne E. M., Maclntyre N., Shaw D. J., Waran N. K., Mahew J., Fleetwood-Walker S. M. (2007) Neuropathic changes in equine laminitis pain. Pain 132 321-331

Minero M., Zucca D., Canalo E. (2006) A note on reaction to novel stimulus and restraint by therapeutic riding horses. Appl. Anim. Behav. Sci. 97, 335-342

Molony V., Kent J. E. (1997) Assessment of acute pain in farm animals using behavioral and physiological measurements. J. Anim. Sci. 75, 266-272

Munsters C. C. B. M., Visser E. K., van de Broek J., Sloet van Oldruitenborgh-Oosterbaan M. M (2012) The influence of challenging objects and horse-rider matching on heart rate, heart rate variability and behavioural score in riding horses. Vet. J. 192, 75-80

Hood D. M. (2003) Laminitis. In: Orsini J.A. and Divers T.J. Manual of Equine Emergencies, Verlag; Saunders Philadelphia, 2. Auflage, 368-376.

Pinna G. D., Maestri R., Torunski A., Danilowicz-Szymanowicz, Szwoch M., La Rovere M.T., Raczak G. (2007) Heart rate variability measures: a fresh look at reliability. Clin. Sci. 113, 131-140

Rietman T. R., Stauffacher M., Bernasconi P., Aver J. A., Weishaupt M. A. (2004) The association between heart rate, heart rate variability, endocrine and behavioural pain measuers in horses suffering from laminitis. J. Vet. Med. A 51, 218-225

Sandercock G. R. H, Bromley P. D., Brodie D. A. (2005) The reliability of short-term measurements of heart rate variability. Int. J. Cardiol. $103,238-247$

Schmidt A., Hödl S., Möstl E., Aurich J., Müller J., Aurich C. (2010a) Cortisol release, heart rate, and heart rate variability in transportnaïve horses during repeated road transport. Dom. Anim. Endocrinol. 39, 205-213

Schmidt A., Biau S., Möstl E., Becker-Birck M., Morillon B., Aurich J., Faure J.-M., Aurich C. (2010b) Changes in cortisol release and heart variability in sport horses during long-distance road transport. Dom. Anim. Endocrinol. 38, 179-189

Schmidt A., Möstl E., Wehnert C., Aurich J., Müller J., Aurich C. (2010c) Cortisol release and heart rate variability in horses during road transport. Hormon. Behav. 57, 209-215

Stewart M., Stafford K. J., Dowling S. K., Schaefer A. L., Webster J. R. (2008) Eye temperature and heart rate variability of calves disbudded with or without local anaesthetic. Physiol. Behav. 94, 789-797

Stewart M., Stookey J. M., Stafford K. J., Tucker C. B., Rogers A. R., Dowling S. K., Verkerk G. A., Schaefer A. L., Webster J. R. (2009) Effects of local anesthetic and a nonsteroidal anti-inflammatory drug on pain responses of dairy calves to hot-iron dehorning. J. Dairy Sci. 92, 1512-1519

Stewart M., Verkerk G. A., Stafford K. J., Schaefer A. L., Webster J. $R$. (2010) Noninvasive assessment of autonomic activity for evaluation of pain in calves using surgical castration as a model. J. Dairy Sci. 93, 3602-3609

Stubsjoen S. M., Flo A. S., Moe R. O., Janczak A. M., Skjerve E., Valle P. S., Zanella A. J. (2009) Exploring non-invasive methods to assess pain in sheep. Physiol. Behav. 98, 640-648

Stubsjoen S. M., Bohlin J., Skjerve E., Valle P. S., Zanella A. J. (2010) Applying fractal analysis to heart rate time series of sheep experiencing pain. Physiol. Behav. 101, 74-80

Task Force of the European Society of Cardiology and the North American Society of Pacing and Electrophysiology (1996) Heart rate variability: Standards of measurement, physiological interpretation, and clinical use. Europ. Heart J. 17, 354-381

Von Borell E., Langbein J., Després G., Hansen S., Leterrier C. (2007) Heart rate variability as a measure of autonomic regulation of cardiac activity for assessing stress and welfare in farm animals - A review. Physiol. Behav. 92, 293-316
Van Eps A. W., Pollitt C. C. (2006) Equine laminitis induced with oligofructose. Equine vet. J. 38, 203-208

Van Eps A. W., Pollitt C. C. (2009) Equine laminitis model: Cryotherapy reduces the severity of lesions evaluated seven days after induction with oligofructose. Equine vet. J. 41, 741-746

Vinuela-Fernandez I., Jones E., Welsh E. M., Fleetwood-Walker S. M. (2007) Pain mechanisms and their implication for the management of pain in farm and companion animals. Vet J. 174, 227-239

Vinuela-Fernandez I., Jones E., McKendrick I. J.. Molony V. (2011) Quantitative assessment of increased sensitivity of chronic laminitic horses to hoof tester evoked pain. Equine vet. J. 43, 62-68

Woolf C. J., Mannion R. J. (1999) Neuropathic pain: aetiology, symptoms, mechanisms and management. Lancet 353, 1959 1964

\section{Die Korrelation von elektrokardiographischen Parametern (Heart Rate Variability und der Herzfre- quenz) mit dem Obel- Grad bei Pferden mit Hufrehe}

Zusammenfassung: Die Herzfrequenzvariabilität (HRV) wurde bereits mehrfach zur Beurteilung von Schmerz und/oder Stress bei nonverbalen Spezies verwendet und wurde in der vorliegenden Studie herangezogen, um den Informationsgehalt der Herzfrequenz (HR), die sehr häufig zur Beurteilung der klinischen Hufrehe herangezogen wird, noch genauer zu analysieren und zwar unter der Voraussetzung, dass eine niedrige HRV einem höheren Schmerzgrad entspricht. HR und HRV wurden bei Pferden mit Hufrehe $(n=12)$ mittels Polar telemetrisches Herzfrequenzmonitoring über mehrere Stunden aufgezeichnet, ausgewertet und mit den Daten gesunder Kontrollpferde $(n=5)$ verglichen. Für die Beurteilung der HRV wurden Sequenzen von 100 und 500 aufeinanderfolgenden Herzschlägen (bts) aus den gesammelten Daten jeder Messung verwendet und der root mean square of successive RR differences (RMSSD) als Parameter der HRV verwendet. Der mittlere HR Wert war bei der ersten Messung nach der Klinikaufnahme signifikant niedriger in der Kontrollgruppe $(40 \pm 2 \mathrm{Schläge/min})$ als in der Gruppe mit Hufrehe $(50 \pm 10$ Schläge/min; $p=0,04)$. Die Analyse des RMSSD der 100 bts (RMSSD100) zeigte einen signifikanten Unterschied zwischen der Kontrollgruppe (162 \pm 9 ) und der Gruppe mit Hufrehe bei der ersten Messung nach ihrer Klinikaufnahme $(140 \pm 20, p=0,04)$, während die Analyse des RMMSD 100 zwischen der Kontrollgruppe und der Gruppe mit Hufrehe ab der zweiten Messung keinen signifikanten Unterschied mehr zeigte. Der Vergleich des RMSSD der 500 bts (RMSSD500) der Kontrollgruppe mit der Gruppe der Hufrehe zeigte bei keiner Messung einen signifikanten Unterschied. Zum Zeitpunkt der ersten Datenerhebung bestand eine hochsignifikante, positive Korrelation zwischen dem Obel Grad und der Herzfrequenz (0.625, $p=0.007$ ), sowie eine hochsignifikante negative Korrelation zwischen dem Obel Grad und dem RMSSD100 (-0.653, $p=0.005)$. Die vorliegende Studie legt nahe, dass die HRV nur einen limitierten Zusatznutzen bei der Schmerzbeurteilung beim Pferd hat. Im Gegensatz dazu ist die $\mathrm{HR}$, die ohnehin ohne jeden Zusatzaufwand im laufenden Klinikbetrieb erhoben wird, ein wichtiger Parameter zur Erhebung 
des Schmerzausmaßes bei chronischer Hufrehe, der sich als einer von mehreren Faktoren für die Prognosestellung eignet.

Schlüsselwörter: Hufrehe / Herzfrequenz /Herzfrequenzvariabilität/ Schmerzbeurteilung/ Pferd

\section{Einleitung}

Schmerz wurde als eine aversive, sensorische und emotionale Erfahrung definiert, durch welche das Tier eine Schädigung oder eine Gefährdung des Gewebes erkennt. Durch den Schmerz verändert sich die Physiologie und das Verhalten um Schäden zu vermindern oder zu reduzieren und um die Wahrscheinlichkeit von erneutem Auftreten zu senken und Heilung zu fördern (Molony 1997).

Schmerz kann als nützlicher, protektiver Schmerz auftreten und ist meist wahrscheinlich entzündlich oder traumatisch bedingt, wobei der durch Entzündung verursachte Schmerz sich meist gut durch entzündungshemmende Medikamente (NSAIDs) kontrollieren lässt (Driessen et al 2007).

Der im Gegensatz dazu ebenfalls vorkommende pathologische Schmerz hat keinerlei biologische Vorteile und führt dazu, dass Individuen leiden und Stress ausgesetzt sind (Woolf et al. 1999). Diese bei der Hufrehe auftretende Schmerzart, die als neuropathischer Schmerz definiert ist, wird durch Verletzungen von sensorischen Nerven und Veränderungen an den Neuronen verursacht und ist durch Hyperalgesie, Allodynie und spontanen Schmerz charakterisiert. Dieser Nervenveränderungen führen dadurch möglicherweise zu chronischem Schmerz mit vermindertem Ansprechen auf Schmerzmedikamente (Jones et al. 2007). Aus der Humanmedizin ist bekannt, dass Patienten neuropathische Schmerzen ständig oder anfallsartig, oft auch unabhängig von Schmerzreizen haben (Woolf et al 1999).

Da der Erkrankungsprozess der Hufrehe eine Kaskade von Veränderungen auslöst, setzł sich der Schmerzkomplex, der vor allem als Entzündungsschmerz durch Gewebeschädigung angesehen wurde, höchstwahrscheinlich zusätzlich auch aus dem nachgewiesenen neuropathischen Schmerz durch Nervenschädigung und dem funktionalen Schmerz durch abnormale Funktion des Nervensystems zusammen (Driessen et al. 2007, Collins et al. 2010).

Da Tiere, die an Hufrehe erkrankt sind, oftmals stark leiden und häufig euthanasiert werden müssen, ist eine Evaluierung des Schmerzgrades aus ethischen, therapeutischen und prognostischen Gründen besonders wichtig (Driessen et al. 2007, Collins et al. 2010, Bussières et al. 2008).

Eine effektive Schmerzbeurteilung sollte möglichst viele Schmerzparameter involvieren (Intensität, Frequenz, Daver, Qualität) und rassen-und speziesspezifisch sein (Ashley et al. 2005). Die Schmerzbeurteilung ist auf sensitive und reproduzierbare Untersuchungsmittel angewiesen, wie zum Beispiel die Untersuchung mit der Hufuntersuchungszange im Fall der Hufrehe (Vinuela-Fernandez et al. 2007,2011).

Für die Schmerzbeurteilung bei der Hufrehe werden sowohl die Beurteilung nach OBEL (Budras et al. 2006), aber auch verschiedene Skalen mit Verhaltensparametern, zum Teil in Kombination mit physiologischen Parametern, herangezogen und geben Aufschluss über das Vorhandensein von Schmerz, aber nicht zwangsläufig über Herkunft und Art oder den genaven Schweregrad.

Um die pathophysiologischen Ereignisse während der Hufrehe auf unterschiedlichste Art und Weise zu untersuchen, wurde sie bereits in zahlreichen Studien experimentell induziert. Diese Studien sind ein essentieller Beitrag zum besseren Verständnis der Hufrehe, auch wenn sie die klinische Realität natürlich erkrankter Pferde nur partiell widerspiegeln. In vielen dieser Studien wurde zur Beurteilung der klinischen Hufrehe auch die Herzfrequenz (HR) untersucht. Signifikante Veränderungen der HR wurden bei Pferden mit durch Oligofructose (OF) induzierter Hufrehe ohne und mit anschließend durchgeführter Kryotherapie (van Eps et al. 2006, 2009) sowie bei auf einer reichhaltigen Weide gefütterten Ponys mit Hufrehe (Hinckely et al. 1996) gefunden. Es wurde mehrfach festgestellt, dass Schmerz bei Hufrehe zu einer Erhöhung der HR führt (Orsini et al. 2003) und auch der Schmerzgrad möglicherweise über das Ausmaß der Erhöhung der HR reflektiert wird (Brown et al. 2002).

Um den Informationsgehalt der HR noch genaver zu analysieren, wurde neben der Dokumentation der HR auch die Herzfrequenzvariabilität (HRV) untersucht, und zwar unter der Prämisse, dass eine niedrige HRV einem höheren Schmerzgrad (Rietmann et al. 2004) oder einer Aktivierung des Sympathikus entsprechen kann (Stewart et al. 2008). Durch diese Variabilität aufeinanderfolgender Herzschläge, lässł sich das autonome Nervensystem mit seinen sympathischen und parasympathischen Einflüssen auf das Herz beurteilen (Task Force of The European Society of Cardiology and The North American Society of Pacing and Electrophysiology 1996).

Dazu liegen zahlreiche Studien an unterschiedlichen Tierarten, jedoch ohne einen konsistenten Analyse-Standard vor. Möglicherweise konnte die HRV Analyse bisher deshalb nicht durchgängig als sinnvolle Ergänzung der Schmerzbeurteilung bestätigt werden. In einer Studie bei Mäusen mit postoperativem Schmerz wurde das Intervall zwischen zwei Herzschlägen (interbeat interval, IBI) und die Standardabweichung dieser Intervalle (SDNN) für die Berechnung der HRV herangezogen. Dabei wurden signifikante Veränderungen der HRV gefunden (Arras et al. 2007). In einer Studie mit Kälbern bei der Enthornung mit oder ohne Lokalanästhesie (LA), bzw. mit LA und NSAID wurden der "root mean square of successive RR differences (RMSSD), sowie die High Frequency (HF, charakterisiert die Aktivität des Parasympathikus) und Low Frequency (LF, charakterisiert die Aktivität des Sympathikus) Anteile, sowie die HF/LF Ratio (spiegelt die sympathovagale Balance wieder) als Parameter der HRV für 512 IBI berechnet und signifikante Veränderungen der HR und teilweise der HRV gefunden (Stewart et al. 2008, Stewart et al. 2009). In einer anderen Studie wurde die HR und HRV von Kälbern bei Kastration mit oder ohne LA untersucht und signifikante Veränderungen der HR und der HRV gefunden (Stewart et al 2010).

Rietmann et al. (2004) untersuchten in einer Hufrehestudie die HR und die HRV im Vergleich mit anderen Parametern. Als Parameter der HRV wurden der RMSSD, die HF, die LF und die HF/LF Ratio ermittelt. Diese Studie ergab signifikante Unterschiede der HR, aber keine signifikanten Unterschiede der Parameter der HRV. 
Im Gegensatz zu der zur Schmerzbeurteilung geeigneten HR (Stewart et al 2010), ist die HRV in den bisher dokumentierten Analyseverfahren für die Beurteilung der Schmerzhaftigkeit von Pferden mit Hufrehe scheinbar nicht aussagekräftig, wenn lediglich in einem Zeitraum von 10 Minuten und weniger ermittelt wird.

Das Ziel der vorliegenden Studie war daher zu untersuchen, ob die HRV als nicht-invasiver und einfach zu ermittelnder Parameter für die Schmerzquantifizierung bei Pferden mit Hufrehe geeignet ist, sowie zu beurteilen, ob diese Methode eventuell auch außerhalb einer Klinik anzuwenden wäre.

\section{Material und Methode}

\section{Tiere}

In dieser Studie wurden 12 Pferde, davon 7 Stuten und 5 Wallachen zwischen 6 und 28 Jahren alt, mit unterschiedlich starker Hufreheerscheinung untersucht (Tabelle 1), wobei jedes für die Studie untersuchte Pferd einen Obel-Grad von mindestens 1 und röntgenologisch nachgewiesene Rotation und/oder Senkung des Hufbeines beiderseits an den Vorderund/oder Hinterextremitäten zeigte. (Tabelle 2).

Alle Pferde waren Patienten des Pferdezentrums der Veterinärmedizinischen Universität Wien, und wurden, unbeeinflusst von der vorliegenden Studie, in der Verantwortung der behandelnden Tierärztinnen und Tierärzte, medikamentös und durch Management-Maßnahmen sowie Veränderungen der Hufform, bzw. Anbringen von diversen Unterstützungen am Huf behandelt. Die Pferde wurden mit nassem Heu gefüttert und durften sich während der Messungen der HRV in der Box frei bewegen bzw. hinlegen. 3 der 12 Pferde mit Hufrehe wurden in der Klinik euthanasiert und 9 Pferde nach unterschiedlich langem Klinikaufenthalt entlassen.

Für die Kontrollgruppe wurden 5 Pferde mit einem ObelGrad 0, sowie frei von Lahmheit im Schritt herangezogen. Zwei Pferde waren Patienten, des Pferdezentrums der Veterinärmedizinischen Universität Wien und 3 Ponys waren im Easter Bush Veterinary Centre der Royal (Dick) School of Veterinary Studies (Universität Edinburgh) stationiert. Die beiden Kontrollpferde des Pferdezentrums, waren Wallachen, ein Araber und ein Appaloosa, 8 und 20 Jahre alt, diese wurden präoperativ für die Messungen herangezogen. Bei den Grunderkrankungen handelte es sich um einen Chip im Tarsalgelenk und um ein Griffelbeinüberbein. Diese Tiere zeigten bei routinemäßig durchgeführten klinischen Untersuchungen auch keinerlei Anzeichen anderer schmerzhafter Prozesse.

\section{Messungen}

Vor jeder Messung wurden die HR und Atemfrequenz (AF) ermittelt. Die HRV wurde kontinuierlich mit dem Polar Herzfrequenzmonitor (s 810 i, Polar Electro Oy, Helsinki, Finland) bei allen Pferden mit Hufrehe innerhalb der ersten 5 Tage nach der Klinikaufnahme an bis zu 3 aufeinanderfolgenden Tagen und danach $1 \mathrm{x}$ in der Woche mindestens 2 und maximal 7 weitere Nächte über mehrere Stunden aufgezeichnet. Die Elektroden wurden nur an bereits stehenden Pferden angebracht und keines der erkrankten Pferde zum Aufstehen gezwungen.
Zwei Elektroden wurden auf der linken Thoraxseite angebracht und mit einer elastischen Bandage rund um den Thorax fixiert. Um eine bessere Leiffähigkeit zu erreichen wurde Ultraschallgel an den Elektrodenpunkten aufgebracht. Der Herzfrequenzmonitor wurde mit einem zusätzlichen elastischen Gurt in Elektrodennähe am Pferd fixiert, um so die bestmögliche Datenübertragung zu erreichen. Während der Messung konnten sich die Pferde frei in der Box bewegen und hinlegen. Die Messungen der Kontrollpferde erfolgten jeweils nur einmal, in einer ruhigen Umgebung, ebenfalls in einer Box.

\section{Datenerhebung}

Die Daten wurden im Herzfrequenzmonitor gespeichert und am nächsten Morgen per Infrarot in die Polar Software auf dem Computer übertragen.

\section{Datenanalyse und HRV}

Die Daten wurden danach in das Programm MS-Excel exportiert und weiter bearbeitet. Um die bei dieser Art der Datenaufzeichnung üblicherweise auftretenden Artefakte auszuschließen, wurden die Daten wie folgt gefiltert: Als Filter wurden die Grenzen der R-R Intervalle bei 600 ms (entsprechend einer Herzfrequenz von 100/min) und $3000 \mathrm{~ms}$ (entsprechend einer Herzfrequenz von 20/min) angesetzt; Werte außerhalb dieser Grenzen wurden verworfen. Darauffolgend wurden R-R Intervall Werte, die sich um mehr als die doppelte Standardabweichung vom arithmetischen Mittelwert unterschieden, ebenfalls von den Daten entfernt. Aus dieser Vorgangsweise ergaben sich fehlende Werte in den Datenreihen, jedoch nur aus ununterbrochenen Datenreihen wurden Sequenzen von 100 (100 bts) und 500 (500 bts) aufeinanderfolgenden Herzschlägen für die Berechnung des rooł mean square of successive RR differences (RMSSD) weiterverwendet. Der RMSSD wurde in der vorliegenden Studie als informativer und am häufigsten verwendete Parameter der HRV herangezogen

\section{Statistik}

Die Prüfung der Normalverteilung der Daten wurde mittels Kolmogorov Smirnov Test durchgeführt und die normalverteilte Daten wurden als Mittelwert (MW) und Standardabweichung (Stabw) dargestellt. Für den Vergleich von der HR Messung 1 bis 5, dem RMSSD100 1 bis 5 und dem RMSSD500 1 bis 5 zwischen der Gruppe Hufrehe gegenüber der Messung der Kontrollgruppe wurde der T-Test für unabhängige Stichproben herangezogen und zweiseitige Signifikanzen wurden berechnet. Die Daten vom Messpunkt 6 und dem Messpunkt 7 wurden nicht für die Statistik herangezogen. Mittels Berechnung des Pearsons Korrelationskoeffizienten wurden die Korrelationen der HR mit dem RMSSD100, der HR mit dem RMSSD500, der HR mit dem Obel-Grad, des RMSSD100 mit dem RMSSD500, des RMSSD100 mit dem Obel-Grad und des RMSSD500 mit dem Obel- Grad ausgewertet.

\section{Resultate}

Die erste Messung fand bei 2 Pferden am Tag der Aufnahme, bei 5 Pferden am Tag 1 nach der Aufnahme, bei 4 Pferden am Tag 2 nach der Aufnahme und bei einem Pferd am Tag 5 
nach der Aufnahme statt. Die zweite Messung fand bei 8 Pferden am darauffolgenden Tag nach der ersten Messung, bei 3 Pferden 2 Tage nach der ersten Messung und bei einem Pferd 14 Tage nach der ersten Messung statt. Die dritte Messung fand bei 7 Pferden am Tag nach der 2. Messung, bei 2 Pferden nach 2 Tagen, bei 1 Pferd nach 3 Tagen und bei einem Pferd nach 11 Tagen statt. Bei 2 Pferden hat keine dritte Messung stattgefunden.

Die Beurteilung der HR ergab bei der ersten Messung nach der Aufnahme eine signifikant niedrigere HR bei der Kontrollgruppe (40 2 Schläge/min) gegenüber den Pferden mit Hufrehe $(50 \pm 10$ Schläge/min; $p=0,04)$. Bei der zweiten Messung nach der Aufnahme war der Unterschied nicht mehr signifikant (Tabelle 3).

Die Resultate des RMSSD100 zeigten einen signifikanten Unterschied zwischen der Kontrollgruppe (162 \pm 9) gegenüber der Gruppe der Pferde mit Hufrehe bei der ersten Messung nach ihrer Klinikaufnahme (140 $\pm 20, p=0,04)$. Bereits bei der 2. Messung zeigte die Analyse des RMSSD100 keinen signifikanten Unterschied mehr zwischen der Kontrollgruppe und den Pferden mit Hufrehe (Tabelle 4). Die Resultate des RMSSD500 zeigten zu keinem Zeitpunkt signifikante Unterschiede zwischen der Kontrollgruppe und der Gruppe mit Hufrehe (Tabelle 5).

Die Herzfrequenz korrelierte mit RMSSD100 hochsignifikant negativ $(-0,937, p=0,000)$ und mit RMSSD500 signifikant negativ $(-0,531 p=0,03)$. RMSSD100 korrelierte mit RMSSD500 signifikant positiv $(0,506, p=0,04)$. Der ObelGrad korrelierte mit der Herzfrequenz der ersten Messung hochsignifikante positiv $(0,625, p=0,007)$ und mit RMSSD100 der ersten Messung hochsignifikant negativ $(-0,653, p=0,005)$. Keine signifikante Korrelation zeigte sich zwischen dem Obel-Grad mit dem RMSSD500.

\section{Diskussion}

In der Studie von Rietmann et al. (2004), in der die HRV bei Pferden mit Hufrehe unter möglichst standardisierten Bedingungen über jeweils 10 Minuten ermittelt wurde, korrelierten die beide Frequenzparameter der HRV mit dem Obel-Grad und dem Grad der Reaktion auf die Hufuntersuchungszange, wobei auch der High Frequency Anteil der HRV mit der laufenden Gewichtsverlagerung von einem Bein aufs andere korrelierte. Auf Grund der Ergebnisse der oben angeführten Studie wurde bei der Messung der HRV in der vorliegenden Studie ein längerer Messzeitraum gewählt, was zwangsläufig die Standardisierung der Messung reduzierte, da die Pferde frei beweglich in der Box gemessen wurden, und nicht wie bei Rietmann et al. (2004) angebunden waren. Das in den Grundzügen ähnliche Ergebnis zeigt, dass die in der vorliegenden Studie gewählte Messmethode der kurzzeitigen Messung nicht überlegen ist.

In einer Studie von Erber et al. (2012) wurde bei der Untersuchung von Kennzeichnungsmethoden von Fohlen, und zwar dem Heißbrennen und der Implantation von Mikrochips im Halsbereich, keine Veränderung der HRV, aber eine Erhöhung der HR gefunden, und zwar ohne signifikanten Unterschied zwischen beiden Maßnahmen. Die Autoren nennen als Ursache, dass ein kurzzeitiger Schmerzimpuls (wie das Heißbren- nen) möglicherweise nicht ausreichend für erkennbare Veränderungen in der HRV ist. Auch bei den in der vorliegenden Studie untersuchten Pferden, die bereits chronisch von den häufig sehr ausgeprägten Schmerzen der Hufrehe betroffen waren, konnte kein eindeutiger Unterschied in der HRV gegenüber einer nicht schmerzhaften Kontrollgruppe festgestellt werden. Daher legt auch die vorliegende Studie nahe, dass die HRV eventuell nur bedingt für die Schmerzbeurteilung beim Pferd einsetzbar ist, und zwar auch beim chronischen, sehr ausgeprägten Schmerz.

Stewart et al (2010) schreiben in ihrer Studie, dass sich HR und HRV gut ergänzen und in Kombination mit der Infrarot Thermografie von Unterlid und Tränenkanal gut für die Schmerzbeurteilung nach Kastration bzw. Enthornung herangezogen werden können. In der vorliegenden Studie zeigte sich die HR der HRV in der Korrelation mit dem Obel-Grad überlegen. Daraus lässt sich allerdings nicht schließen, dass die Kombination verschiedener Parameter nicht genauer ist, als die alleinige Verwendung der HR. Jedoch lässt sich die Verwendung der HR, die ohnehin ohne Zusatzaufwand im laufenden Klinikbetrieb erhoben wird, als wichtigen Parameter zur Erhebung des Schmerzes bei chronischer Hufrehe in der vorliegenden Studie bestätigen.

Stubsjoen et al. (2009) fanden in ihrer Studie einen niedrigeren RMSSD und SDNN in Verbindung mit einer höheren HR, und schätzen die HRV als gute Methode ein, um moderaten Schmerz zu beurteilen wobei die eher kleine Anzahl an untersuchten Schafen $(n=6)$ limitierend sein könnte. Diese Korrelation war auch in der vorliegenden Studie vorhanden. Weil sie von der Berechnungsmethode abhängig ist, wurden RMSSD100 und RMSSD500 berechnet.

In einer anderen Studie fanden Stubsjoen et al. (2010) überraschender Weise keine Unterschiede des Koeffizienten alpha der HRV, wobei auch hier möglicherweise die geringe Anzahl an Tieren $(n=6)$ die Ursache sein könnte.

In der vorliegenden Studie stand eine prinzipiell ausreichende Anzahl an Pferden mit Hufrehe zur Verfügung, doch wäre eine nachfolgend beschrieben Standardisierung vorteilhaft. Die Messung der Kontrollpferde in der vorliegenden Studie diente dazu, den Zusammenhang zwischen den erhobenen Werten HR, RMSSD100 und RMSSD500 von gesunden Pferden zu dokumentieren. Auf Grund der geringen Anzahl an Kontrollpferden wurden zusätzlich Vergleichswerte von gesunden Pferden aus anderen Studien herangezogen (Tabelle 7).

Arras et al (2007) erklären in ihrer Studie, dass die HR und HRV bei der Beurteilung von postoperativem Schmerz nützlich sein können, wenn die Messungen unter standardisierten Bedingungen in ungestörter Umgebung stattfinden. Die Dokumentation von Schmerz mittels Messung unter standardisierten Bedingungen bei der Hufrehe unterschiedlicher Pferde erscheint schwierig, wie die Ergebnisse der Studie von Rietmann et al 2004 zeigen. Diese Autoren halten es jedoch für möglich, dass z.B. bei der Untersuchung von Pferden derselben Altersgruppe und Rasse eine Schmerzquantifizierung mittels HRV Analyse durchführbar ist. Studien mit einer definierten Population an Pferden stehen derzeit noch aus. Studien, die Schmerz nach einer gleichartigen schmerzverursachenden Intervention mittels HRV quantifizieren konnten, 
waren an anderen Tieren gleicher Rassen durchgeführt worden (Kälber: Stewart et al. 2008, 2009, 2010, Schafe: Stubsjøen et al 2009).

Rietmann et al. (2004) erklären in ihrer Studie, dass in Zukunft die HRV mit einer größeren Anzahl und einheitlichen Patienten untersucht werden sollte, da die Krankheitsdaver und Rasse die HRV beeinflussen können. Dies ist jedoch bei einer Population von an eine Klinik überwiesenen Pferden mit Hufrehe, wie in der vorliegenden Studie, schwer möglich. Die Schwierigkeit konsistente Hufrehe zu untersuchen, zeigt sich auch dadurch, dass sogar bei experimentell induzierter Hufrehe, trotz gleicher Induktionsmethode und gleichen Pferderassen (Galey et al. 1991, van Eps et al. 2006) bzw. bei gleicher Induktionsmethode und unterschiedlichen Ponyrassen (Hinkkley et al. 1996) unterschiedliche Obel-Grade resultierten.

Stewart et al. (2008) sehen in der Anwendung der HRV Vorteile, wenn akute Schmerzantworten beurteilt werden. Pferde die mit Hufrehe in der Klinik stationär behandelt werden, leiden zwar unter starken Schmerzen, diese sind jedoch nicht vorwiegend hoch akut. So zeigte in der vorliegenden Studie kein Pferd vorberichtlich weniger als 12 bis 24 Stunden der Hufrehesymptomatik. Bei der überwiegenden Anzahl der Pferde war die Hufrehe bereits seit mehreren Tagen klinisch manifest. 8 Pferde wurden bereits vor der Aufnahme an der Klinik mit NSAID und anderen Medikamenten versorgt, 2 Pferde wurden mehrere Wochen vor der Klinikaufnahme mit NSAID versorgt, waren zum Zeitpunkt der Klinikaufnahme aber ohne Medikation und 2 Pferde wurden ohne Therapie mit NSAID aufgenommen. Aus diesem Aspekt ist auch der bei einem Pferd sogar 5 Tage betragende Abstand zwischen der Klinikaufnahme und der ersten Messung zu beurteilen. Eine Messung zum Zeitpunkt des Auftretens der ersten klinischen Symptome bei akuter oder zu wissenschaftlichen Untersuchungen induzierter Hufrehe erscheint vorteilhaft für eine aussagekräftige Beurteilung der HRV als Schmerzparameter.

Stewart et al. (2009) fanden in einer Studie nur Veränderungen beim RMSSD und sehen eine mögliche Erklärung in der Verwendung von 512 RR Intervallen, während in der Studie mit anderen Ergebnissen 5-minütige Sequenzen berechnet wurden.

Die Art der Datenerhebung hat offensichtlich einen Einfluss auf die Ergebnisse zur Schmerzbeurteilung mit Hilfe der HRV. Bei der HRV von Pferden scheint es große interindividuelle Unterschiede zu geben, diese sind möglicherweise bedingt durch Genotyp, Verhalten, Temperament und Ernährungszustand (van Borell et al. 2007). Durch diese größere Variabilität der Daten als beim Menschen gibt es derzeit keine allgemein etablierte Methode zur Analyse der HRV und daher soll- te die Interpretation der HRV Daten mit Vorsicht erfolgen. (Munsters et al. 2012).

Van Borell et al. (2007) fordern zur Methode der HRV-Analyse, dass für eine Verwendung der HRV Alter, Geschlecht und Tageszeiten standardisiert und angeführt werden sollten. Auf Grund der individuellen Einflüsse ist der Vergleich der HRV, die vor und nach einer Behandlung gemessen wurde, aussagekräftiger als ein Vergleich von verschiedenen Gruppen. Dieses wurde in der vorliegenden Studie für alle Pferde mit Hufrehe berücksichtigt. Die Sequenzen der Interbeatintervalle sollten für die Analyse mindestens 5 Minuten bzw. um die 500 bts umfassen, dies wurde in der vorliegenden Studie für alle Pferde zumindest bei einer Messung erreicht. Auch in der vorliegenden Studie fehlt diese Standardisierung insofern, als dass die untersuchten Pferde mit Hufrehe in Rasse, Geschlecht, Alter und Ausprägungsgrad der Hufrehe differierten.

Durch die zahlreichen Artefakte war es nicht bei jeder Messung möglich Sequenzen von 500 bts zu beurteilen. Deshalb wurden zusätzlich Sequenzen mit 100 bts analysiert, da solche in ausreichender Anzahl erfasst werden konnten. Die HRV-Analyse von lediglich RMSSD100 erscheint bei der Untersuchung von Tieren mit wenig Einschränkungen des Verhaltensmusters aussagekräftig. Zumindest konnte in der vorliegenden Studie kein signifikanter Unterschied bei dem Vergleich von Analysen von RMSSD500 zwischen der Kontrollgruppe und der Gruppe mit Hufrehe festgestellt werden, umgekehrt konnten jedoch bei der ersten Messung signifikante Unterschiede beim Vergleich des RMSSD100 zwischen den beiden obengenannten Gruppen festgestellt werden. Ab der zweiten Messung wurden auch bei RMSSD100 keine signifikanten Unterschiede mehr gefunden. Zusätzlich zeigten sich in der vorliegenden Studie eine hochsignifikant negative Korrelation der HR mit RMSSD100 und eine hochsignifikant negative Korrelation des Obel-Grads mit RMSSD100.

Munsters et al. (2012) stellen fest, dass weitere Forschungen notwendig sind, um Methode, Verlässlichkeit und Sinnhaftigkeit der HRV-Analyse bei Pferden beurteilen zu können. Auch in der Humanmedizin, wo diese Methode häufiger eingesetz† wird und auch ihren Ursprung hat, wird beschrieben, dass für die Analyse der HRV einheitliche Methoden und standardisierte Bedingung notwendig wären, und die Messsituationen so einheitlich wie möglich sein sollten (Sandercock et al. 2005, Pinna et al. 2007).

Auch mit der vorliegenden Studie an Pferden mit nativer Hufrehe kann eine Verwendung der HRV als klinischer Parameter zur Einschätzung des Verlaufs einer Hufrehe nicht begründet werden. Die Analyse der HRV ist zur Schmerzbeurteilung der Analyse der Herzfrequenz offensichtlich unterlegen. 